\title{
Storage of caatinga forest biomass to improve the quality of wood for energy
}

\section{Estocagem de biomassa florestal da caatinga para melhoria da qualidade energética da madeira}

\author{
Martha Andreia Brand ${ }^{\mathrm{I}}$ Stephenson Ramalho Lacerda ${ }^{\text {II }}$ Juliana de Oliveira ${ }^{\text {III }}$ \\ Gisele Paim Ribeiro Domingues Lopes ${ }^{\mathrm{III}}$ Nayara Bergamo Casagrande ${ }^{\mathrm{IV}}$
}

\section{ABSTRACT}

This study aimed to evaluate the quality of forest biomass energy, coming from the Caatinga, for different storage times in the field. The study was conducted in southern Piaui, between January and February (rainy season). Samples were collected containing branches and trunks of various species, and samples of branches and trunks separately in 5 sample units of $20 \times 20 \mathrm{~m}$. Samples were evaluated in the general state freshly harvested and samples of branches and logs after 15 and 30 days of storage in piles in the field. The analyzes carried out were: moisture content on wet basis, ash content and calorific value. Moisture content of freshly harvested biomass ranged from $39 \%$ with two days after cutting to 79\% in biomass cut and left distributed in the field for 10 days. After storage in piles for 15 days, branches showed moisture content of $18 \%$ and the logs $21 \%$, and net calorific value of $3432 \mathrm{kcal} \mathrm{kg}^{-1}$ and $3274 \mathrm{kcal} \mathrm{kg-1}^{-1}$, respectively. After 30 days, moisture content for branches was $13 \%$ and the $\log _{5} 21 \%$, and net calorific value of $3672 \mathrm{kcal} \mathrm{kg}^{-1}$ and $3240 \mathrm{kcal} \mathrm{kg}^{-1}$, respectively. Ash content of the biomass was low. Cutting trees in the rainy season, with maintenance of biomass in the field for 10 days, resulted in an increment of moisture content. Branches had the best behaviour during the storage. Fifteen days of storage are sufficient for the caating a biomass to achieve highquality energy.

Key words: firewood, Piauí, calorific value, moisture content.

\section{RESUMO}

Este trabalho teve como objetivo avaliar a qualidade energética da biomassa florestal, oriunda da caatinga, em função de diferentes tempos de estocagemno campo. Otrabalhofoidesenvolvido na região sul do Piauí, entre janeiro e fevereiro (época de chuvas). Foram coletadas amostras gerais, contendo galhos e troncos de várias espécies, e amostras de galhos e troncos separadamente, em 5 parcelas de 20x20m. As amostras gerais foram avaliadas no estado recém colhido e as amostras de galhos e toras após 15 e 30 dias de estocagem em pilhas. As análises realizadas foram: teor de umidade na base úmida; teor de cinzas e poder calorífico. O teor de umidade da biomassa recém colhida variou de 39\% com dois dias após o corte a 79\% em biomassa cortada e deixada distribuída no campo por 10 dias. Após estocagem em pilhas por 15 dias, os galhos ficaram com teor de umidade de $18 \%$ e as toras com $21 \%$, e poder

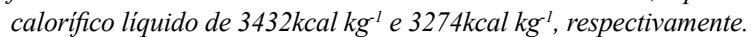
Após 30 dias, os galhos ficaram com $13 \%$ e as toras com $21 \%$ de

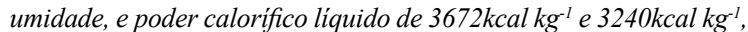
respectivamente. $O$ teor de cinzas da biomassa foi baixo. O corte das árvores na época de chuva, com manutenção da biomassa em campo por 10 dias, proporcionou aumento do teor de umidade. Os galhos tiveram melhor comportamento durante a estocagem. Quinze dias de estocagem são suficientes para a biomassa da caatinga atingir alta qualidade energética.

Palavras-chave: lenha, Piauí, poder calorifico, teor de umidade.

\section{INTRODUCTION}

Caatinga is a mosaico of thorny bushes and seasonally dry forests with over 2.000 species of vascular plants, fishes, reptiles, amphibians, birds and mammals (LEAL et al., 2005). The most important uses of the caatinga are: constructions $(70,49 \%$ of the species), medicines (65,57\%) (SANTOS et al., 2008), and fuel $(54,91 \%)$ (FRANCELINO et al., 2003; SANTOS et al., 2008; RAMOS et al., 2008).

\footnotetext{
IDepartamento de Engenharia Florestal, Centro de Ciências Agroveterinárias, Universidade do Estado de Santa Catarina (UDESC), Av. Luiz de Camões, 2090, 88520-000, Lages, SC, Brasil. E-mail: martha.brand@udesc.br. Corresponding author.

"Empresa Mata Branca, Crato, CE, Brasil.

IIICentro de Ciências Exatas e Tecnológicas, Universidade do Planalto Catarinense (UNIPLAC), Lages, SC, Brasil.

${ }^{\text {IV}}$ Programa de Pós-graduação em Engenharia Florestal, Centro de Ciências Agroveterinárias, Universidade do Estado de Santa Catarina (UDESC), Lages, SC, Brasil. 
As fuel, the firewood can be used as an energy source for industries, trades and houses, and as charcoal (PAREYN, 2010). Firewood can be the main purpose of the exploration of the caatinga, or obtained from opening areas for plantig in shifting cultivation (SCHACHT et al., 1989). According to SAMPAIO (2010), in the neighborhood of big cities, the firewood production, which was once a byproduct of the opening areas of shifting cultivation, became an independent activity.

PAUPITZ (2010) highlighted that seasonality of the production is an important feature of agricultural production and incorporation of forest tracks to produce firewood, charcoal, fiber extractions, fruits and medicinal herbs could allow a growth of the families income, especially during the drought, after harvest and during the pre-harvest period, and according to PAUPITZ (1989) it guarantess the survival of several small farmers, especially during the drought, which affects food production capacity and the nuclear family survival.

According to the law $\mathrm{n}^{\mathrm{o}} 11.284$ (BRASIL, 2006), is possible to enable the forestry exploration in large territories, creating profitable activities for the local population and ensuring the sustainable management of resources. By the dealership management it would be possible to incorporate large forest areas to produce, on an industrial scale, firewood and charcoal, in the West of Bahia and the South of Piauí.

Therefore, the alternative soil use, without the concomitant deployment of forest management plans which guarantees the maintenance of native vegetation can lead to environmental collapse of the existing ecosystem. In addition to the environmental advantages, sustainable use projects, that are fundamental in economic and environmental aspects for the regions such as the Northeast (BRAND et al., 2009).

Besides that, although, the intensive use of the caatinga as fuel, little is known about the amount of biomass which are removed and recycled from the parts of the plants used for this purpose (SILVA \& SAMPAIO, 2008). Thus, this study aimed to evaluate the quality of forest biomass, coming from the caatinga, for different storage times in the field, for energy generation.

\section{MATERIALS AND METHODS}

\section{Description of the study area}

The study was conducted in a private enterprise, called Condomínio Fazenda Chapada do Gurguéia, in the South of Piauí, state of Brazil. The townhouse lands belong to two municipalities:
Redenção do Gurguéia and Morro Cabeça no Tempo. Headquarters of theses municipalities are located, respectively, to the Northwest and Southwest of the property's headquarters, which is located between the geographic coordinates $9^{\circ} 29^{\prime} 03^{\prime \prime}$ and $9^{\circ} 53^{\prime} 16^{\prime \prime}$ $\mathrm{S}, 43^{\circ} 51^{\prime} 35^{\prime \prime}$ and $44^{\circ} 25^{\prime} 13^{\prime \prime} \mathrm{W}$ (TONIOLO et al., 2005) (Figure 1).

According to TONIOLO et al. (2005), the enterprise has a total area of $114.755 \mathrm{ha}$, it is located on the top of a sedimentary sandstone plateau, called "Serra Vermelha". The townhouse area is situated entirely in the Great Landscape Unit of the Intermediate Plateaus and in the Geoenvironmetal Unit of the Southern Tip Plateaus of Piauí (B2), according to the Agroecological Zoning of northeastern Brazil.

The region is situated in the transition of Semi-arid Tropical to Dry Sub-humid Tropical. The dry season is from May to October and the rainy season is from November to April, being March the wettest month, with an anual average precipitation of $850 \mathrm{~mm}$ (TONIOLO et al., 2005). Maximum temperatures range from $29,4^{\circ} \mathrm{C}$ in February to $36^{\circ} \mathrm{C}$ in September, with maximum annual average of $32,6^{\circ} \mathrm{C}$ and minimum annual average of $19,1^{\circ} \mathrm{C}$. Relative humidity presents monthly averages of $43 \%$ in August (the lowest) to $80 \%$ in January (the highest), with annual average rate of $62,2 \%$ (TONIOLO et al., 2005).

Vegetation of the area can be termed as Forested Steppe Savanna (caatinga) according to the IBGE classification (1992). In the study conducted for this research were identified 66 species in the forest formation. The vegetation has 19 species more abundant, representing $76 \%$ of the diversity. The most common species were: goiaba brava (Eugenia sp.), joão mole (Pisonia sp.), canela de velho (Cenostigma gardnerianum), marmela (Desmodium discolor), açoita cavalo (Luehea sp.), figueirinha da caatinga (unidentified) and pau de casca (unidentified). The vegetation has a high floristic diversity for a biome with strong restriction on growth as water deficit.

Relative to the amount of biomass to generate energy produced in the study area, the average stock of firewood was estimated around $150 \mathrm{~m}^{3} \mathrm{ha}^{-1}$ or $400 \mathrm{st} \mathrm{ha}^{-1}$, with an average biomass production of $170 \mathrm{t}$ of wet biomass ha-1. Vegetation also presented an average height of 5,6m, with 4205 trees ha ${ }^{-1}$. Forest has a high population density, with a predominance of individuals with small diameter $(52 \%$ of the population between 2 and $5 \mathrm{~cm}$ of diameter). The largest amount of biomass is concentrated in diameter classes greater than $10 \mathrm{~cm}(84 \%$ of total wet biomass available for energy generation). 


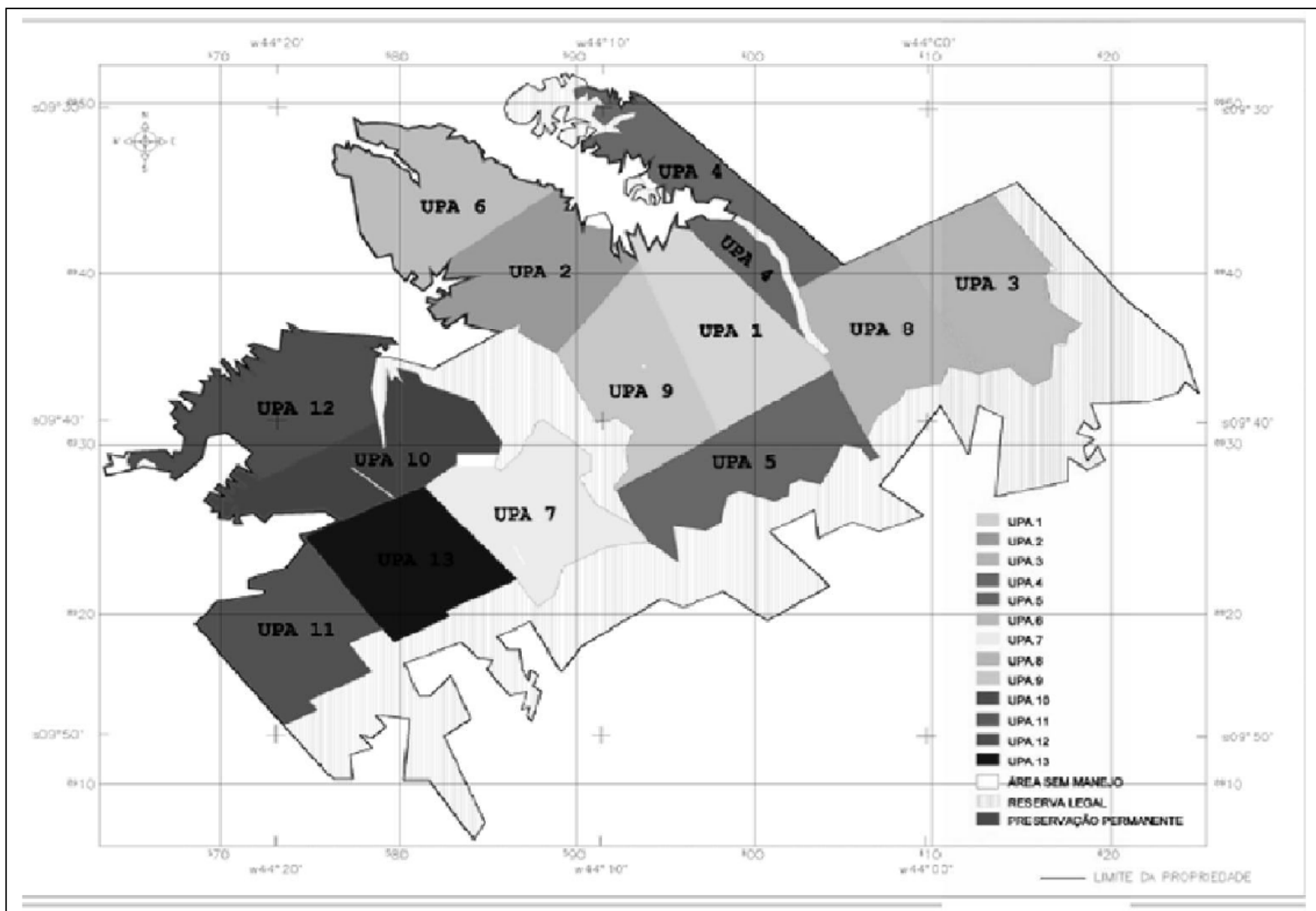

Figure 1 - Project area of the sustainable management of the Caatinga, in southern Piauí. Fonte: TONIOLO et al. (2005).

The energy analysis of biomass at different times of harvest revealed that in gathering made between May and June (end of the rainy season) the average moisture content of wood of eight forest species was $29 \%$, average basic density of $716 \mathrm{~kg} \mathrm{~m}^{-3}$, ash content of $1,59 \%$ and gross calorific value of $4701 \mathrm{kcal} \mathrm{kg}^{-1}$. Although in gathering made in October and November (end of the dry season in the region), the values were $28 \%$ for moisture content of wood for 28 forest species, average basic density of $735 \mathrm{~kg} \mathrm{~m}^{-3}$, ash content of $1,53 \%$ and gross calorific value of $4583 \mathrm{kcal} \mathrm{kg}^{-1}$.

Determination of the energy quality of forest biomass of the caatinga for different storage time

The gathering of wood species belonging to the forest formation in the study was conducted between January 20 and February 1 in 2008 (rainy season). Five samples units of $20 \times 20 \mathrm{~m}$ were marked beside of the inventoried sample units for the production of the Management Plan carried out by TONIOLO et al. (2005).

These sample units, along with 12 other sample units were deployed to quantify the biomass of the vegetal formation for energy generation. However, only the five sample units described in table 1 were used to study the storage of biomass. After the location and demarcation of the sample units, the preliminar cleaning of the area was held with machete for subsequent entry of the chainsaws for trees felling. All the trees were felled, delimbed and drawn into logs with lengths between 1,00 to $1,50 \mathrm{~m}$ and the branches with similar or smaller size to this length.

After the cutting and drawing of biomass, the material was loaded onto a truck or a tractor trailer, for weighing on electronic highway scales to obtain the amount of biomass produced in each sample unit. After weighing, biomass of trunks and branches was stored in an unpaved patio, in open area of vegetation, in conical piles, made separately for branches and trunks. Each sample unit had two piles, one of branches and other of trunks, totaling 10 piles.

Table 1 shows the trees cutting and drawing dates, date on which the biomass was removed from sample units and placed in storage in piles and dates on which the gatherings were made in piles to 
Table 1 - Installed sample units and gathering dates for analysis the energy quality of the wood, according to storage time.

\begin{tabular}{lcccc}
\hline Sample Unit & Cutting and drawing & Storage & Gathering (15 days of storage) & Gathering (30 days of storage) \\
\hline 15 & $21 / 01 / 2008$ & $31 / 01 / 2008$ & $14 / 02 / 2008$ & $29 / 03 / 2008$ \\
20 & $26 / 01 / 2008$ & $30 / 01 / 2008$ & $14 / 02 / 2008$ & $29 / 02 / 2008$ \\
21 & $27 / 01 / 2008$ & $30 / 01 / 2008$ & $14 / 02 / 2008$ & $29 / 02 / 2008$ \\
33 & $28 / 01 / 2008$ & $30 / 01 / 2008$ & $14 / 02 / 2008$ & $29 / 02 / 2008$ \\
34 & $30 / 01 / 2008$ & $30 / 01 / 2008$ & $14 / 02 / 2008$ & $29 / 02 / 2008$ \\
\hline
\end{tabular}

evaluate the influence of the storage on the quality of biomass energy.

Thus, only in the sample unit 15 , the biomass stayed in the field for 10 days, distributed in the area of the sample unit, before being placed under storage in piles. For the remaining sample units, the time ranged from 0 to 4 days of permanency in the field before storage, in piles, in open courtyard.

From the sample units 15 to 33 were gathered samples composed by mixing of the branches and the trunks of all component species on the sample unit to determine the moisture content immediately after the cutting (sample unit 33) and after staying for 10 days in the field (sample unit 15). For all the sample units were collected samples separately for branches and trunks with 15 and 30 days of storage in the open courtyard under direct sunlight.

In all gatherings, discs and branches were placed separately in sealed plastic containers, identified and sent to the laboratory. The physical and energetic analyzes evaluated were: moisture content on wet basis, according to NBR 14929 (ABNT, 2003b); ash content $\left(525^{\circ} \mathrm{C}\right)$, according to NBR 13999 (ABNT, 2003a) and gross and net calorific value in calorimeter, according to the standard DIN 51900 (DIN, 2000). All data were submitted to statistical analysis, using ANOVA/MANOVA and the Tukey test (Tukey $\mathrm{P}>0.05$ ), with the program StatSoft.

\section{RESULTS AND DISCUSSION}

Regarding the physical and energetic properties of the freshly harvested forest biomass (branches and trunks mixed), the moisture content ranged from $79 \%$ (sample unit 15) for biomass of branches and trunks that stayed in the field for 10 days before the storage in piles on the open courtyard, to $39 \%$ (sample unit 33) for the biomass that was left only two days in the field.

Storage of biomass in the field, distributed in the soil, covering the sample unit area, for 10 days was adopted to provide the fall of the leaves, preventing the remove of the total vegetal covering of the ground. This management was adopted in the experiment to minimize or prevent the erosion, whereas the soil in the area was sandy and the gathering was made in the rainy season.

The permanence of leaves, in the field, contribute to the cycling of nutrients in the soil. In study conducted by SILVA et al. (2009) in the transition forest area Amazon-Cerrado in the North of Mato Grosso, which aimed to verify the participation of the leaves in the nitrogen return, phosphorus and carbon to the soil through decomposition in the dry season and the rainy season, the authors reported that the decomposition of leaf litter exclusive of leaves was more intense in the rainy season. Furthermore, because the leaves have higher moisture content they reduce the quality of biomass energy.

Thus, related to the moisture content of branches and trunks biomass of trees that were cut and remained in the field for 10 days before the gathering, for energy analysis and installation of the stored piles (sample unit 15), the moisture content was too high. The value of $79 \%$ was high, both overall, as compared to the biomass of cut trees that only remained two days in the field before the gathering and installation of the storage piles (sample unit 33). Moisture content of the biomass of sample unit 33 was the closest to that observed in the same area, for the wood of different species collected in the rainy season $(29 \%)$.

Considering also moisture loss of the branches and trunks biomass of the two sample units after 15 days under storage in piles, the biomass dried considerably, reaching moisture content below $25 \%$, both for branches and trunks. This moisture content is already considered excellent for energy generation, according to BRAND (2010).

General ash content values for the two sample units were low, ranging from $1,24 \%$ for sample unit 15 to $1,80 \%$ for sample unit 33 . These values were similar to those obtained for the same 
sample units after 15 and 30 days of storage. Gross calorific value $\left(4609 \mathrm{kcal} \mathrm{kg}^{-1}\right.$ for sample unit 15 and $4550 \mathrm{kcal} \mathrm{kg}^{-1}$ for sample unit 33), was consistent with values obtained for the wood of Angiosperms, as mentioned by BRAND (2010). The net calorific value of the sample unit 15 (442 $\mathrm{kcal} \mathrm{kg}^{-1}$ ) was very low, precluding the use of wood for energy generation in these conditions, due to the high moisture content. The net calorific value of the sample unit $33\left(2357 \mathrm{kcal} \mathrm{kg}^{-1}\right)$ was high.

Table 2 shows the values of the physical and energetic properties of the biomass of branches and trunks at different storage times. Concerning to the branches storage, the biomass behaviour was excellent, with high moisture loss over the 30 days of storage, with a statistical variation between 15 and 30 days for all analyzed sample units. Ash content of the branches was low and the net calorific value was high, which provides excellent energy efficiency of wood in energy generation systems.

The logs had lower moisture loss over the storage time, and for some sample units there was moisture gain between 15 and 30 days of storage. Ash content was also low for the logs, and the net calorific value, although, lower than the branches can still be considered high.
Analyzing the energy quality of the branches and trunks according to the storage time, notice that the branches had higher moisture loss, ranging from 19 to $42 \%$ of moisture loss between 15 and 30 days of storage and energy gains in the net calorific value between 1 and $15 \%$ in the same period.

Although the logs lose moisture significantly during storage, they did not have a moisture loss so high between 15 and 30 days, ranging from $-26 \%$ (water gain) to $14 \%$ of moisture loss. Since the energy gains varied from $-8 \%$ (reduction of the net calorific value between 15 and 30 days of storage) to gains of $5 \%$.

For the ash content and gross calorific value, despite the statistical test has shown a variation between the storage time, the observed variations can not be attributed to storage. Furthermore, for all situations (freshly harvested biomass, with 15 and 30 days of storage) the ash content was low.

Analyzing jointly, results obtained in this study agree with the statements made by BRAND et al. (2010). These authors conducted a study of $\log$ storage of Pinus e Eucalyptus for periods that ranged from 2, 4 and 6 months for energy use. The conclusions of the study were that the storage time influenced the moisture content and net calorific

Table 2 - Physical and energetic properties of forest biomass of branches and trunks in different storage periods, in the South of Piauí.

\begin{tabular}{|c|c|c|c|c|c|c|c|c|c|c|c|c|c|c|c|}
\hline \multirow{3}{*}{$\begin{array}{l}\text { Sample unit (branches) } \\
15\end{array}$} & \multicolumn{4}{|c|}{----------(MC - \%)--------- } & \multicolumn{4}{|c|}{--------(AC - \%)-------- } & \multicolumn{4}{|c|}{------(GCV - kcal kg $\left.{ }^{-1}\right)$------ } & \multicolumn{3}{|c|}{-----(NCV - kcal kg-1)----- } \\
\hline & \multicolumn{2}{|c|}{---15 days--- } & \multicolumn{2}{|c|}{---30 days--- } & \multicolumn{2}{|c|}{---15 days--- } & \multicolumn{2}{|c|}{---30 days--- } & \multicolumn{2}{|c|}{---15 days--- } & \multicolumn{2}{|c|}{---30 days--- } & \multicolumn{2}{|c|}{---15 days--- } & --30 days-- \\
\hline & 16 & $\mathrm{a}$ & 12 & $\mathrm{~b}$ & 1.33 & $\mathrm{a}$ & 1.12 & $\mathrm{~b}$ & 4659 & $\mathrm{~b}$ & 4898 & $\mathrm{a}$ & 3545 & $\mathrm{~b}$ & 3953 a \\
\hline 20 & 22 & $\mathrm{a}$ & 13 & $\mathrm{~b}$ & 1.92 & $\mathrm{a}$ & 1.75 & $\mathrm{~b}$ & 4676 & $\mathrm{a}$ & 4738 & $\mathrm{a}$ & 3262 & $\mathrm{~b}$ & 3762 a \\
\hline 21 & 19 & $\mathrm{a}$ & 12 & $\mathrm{~b}$ & 1.35 & $\mathrm{~b}$ & 1.71 & $\mathrm{a}$ & 4858 & $\mathrm{a}$ & 4477 & $\mathrm{~b}$ & 3558 & $\mathrm{a}$ & 3583 a \\
\hline 33 & 16 & $\mathrm{a}$ & 13 & $\mathrm{~b}$ & 1.90 & a & 1.45 & $\mathrm{~b}$ & 4544 & $\mathrm{a}$ & 4512 & $\mathrm{a}$ & 3448 & $\mathrm{~b}$ & 3566 a \\
\hline 34 & 17 & $\mathrm{a}$ & 14 & $\mathrm{~b}$ & 1.89 & $\mathrm{a}$ & 1.43 & $\mathrm{~b}$ & 4478 & $\mathrm{a}$ & 4485 & $\mathrm{a}$ & 3346 & $\mathrm{~b}$ & 3494 a \\
\hline Mean & 18 & & 13 & & 1.68 & & 1.49 & & 4643 & & 4622 & & 3432 & & 3672 \\
\hline SD & 2.25 & & 0,57 & & 0.29 & & 0.24 & & 138 & & 177 & & 121 & & 174 \\
\hline \multirow{2}{*}{ Sample Unit (trunks) } & \multicolumn{4}{|c|}{---------(MC - \%)--------- } & \multicolumn{4}{|c|}{----------(AC - \%)---------- } & \multicolumn{4}{|c|}{------(GCV - kcal kg $\left.{ }^{-1}\right)$------ } & \multicolumn{3}{|c|}{-----(NCV - kcal kg $\left.{ }^{-1}\right)$----- } \\
\hline & \multicolumn{2}{|c|}{---15 days--- } & \multicolumn{2}{|c|}{---30 days--- } & \multicolumn{2}{|c|}{---15 days--- } & \multicolumn{2}{|c|}{---30 days--- } & \multicolumn{2}{|c|}{---15 days--- } & \multicolumn{2}{|c|}{---30 days--- } & \multicolumn{2}{|c|}{---15 days--- } & --30 days-- \\
\hline 15 & 21 & $\mathrm{a}$ & 18 & $\mathrm{~b}$ & 1.90 & $\mathrm{a}$ & 0.85 & $\mathrm{~b}$ & 4581 & $\mathrm{a}$ & 4619 & $\mathrm{a}$ & 3237 & $\mathrm{~b}$ & 3414 a \\
\hline 20 & 25 & $\mathrm{a}$ & 23 & $\mathrm{~b}$ & 2.46 & $\mathrm{a}$ & 1.54 & $\mathrm{~b}$ & 4596 & $\mathrm{a}$ & 4590 & $\mathrm{a}$ & 3054 & $\mathrm{a}$ & 3146 a \\
\hline 21 & 19 & $\mathrm{~b}$ & 24 & $\mathrm{a}$ & 1.80 & $\mathrm{a}$ & 0.83 & $\mathrm{~b}$ & 4713 & $\mathrm{a}$ & 4661 & $\mathrm{a}$ & 3441 & $\mathrm{a}$ & 3152 \\
\hline 33 & 23 & $\mathrm{a}$ & 21 & $\mathrm{~b}$ & 1.33 & $\mathrm{a}$ & 1.28 & $\mathrm{a}$ & 4837 & $\mathrm{a}$ & 4568 & $\mathrm{~b}$ & 3337 & $\mathrm{a}$ & 3227 \\
\hline 34 & 20 & $\mathrm{a}$ & 21 & $\mathrm{a}$ & 1.97 & $\mathrm{a}$ & 2.19 & $\mathrm{a}$ & 4604 & $\mathrm{a}$ & 4613 & $\mathrm{a}$ & 3304 & $\mathrm{a}$ & 3262 a \\
\hline Mean & 21 & & 21 & & 1.89 & & 1.34 & & 4666 & & 4610 & & 3274 & & 3240 \\
\hline $\mathrm{SD}$ & 2.43 & & 2,13 & & 0.37 & & 0.52 & & 132 & & 33 & & 149 & & 101 \\
\hline
\end{tabular}

Note: For each evaluated property (moisture content, ash content, gross and net calorific value) the averages, IN THE LINE, followed by the same letters do not differ statistically between them according to the storage time (15 and 30 days) (Tukey P $>0,05)$.

Abbreviations: Moisture content (MC - \%); Ash content (AC - \%); Gross calorific value (GCV - kcal kg ${ }^{-1}$ ); Net calorific value (NCV - kcal $\mathrm{kg}^{-1}$ ); Standard Deviation (SD). 
value, however it did not influence the gross calorific value and ash content.

Furthermore, BRAND et al. (2011) also stated that in log storage for use in energy generation: the species; storage time; haverst season; storage time and the biomass particle size (logs, edges, branches, wood chips) influence the energy quality of forest biomass. These influences take place so that the storage time improves the quality of the biomass to some extent, before starting the process of biodegradation. Therefore, increasing the storage time for very long periods can reduce the energy quality of the wood.

Regarding the harvest season, harvesting made in warmer seasons and with less rainfall reflected in the lower moisture content of freshly cut wood. Storage time also determines the energy gain speed, where warmer and dry seasons are more beneficial to the energy gain. Beyond that, the smaller particle size of the biomass provides better drying behaviour during storage (BRAND et al., 2010; BRAND et al., 2011), especially when comparing branches and logs.

\section{CONCLUSION}

The cutting of trees during the rainy season, in southern Piauí, and the maintenance of the biomass in the field for the fall of the leaves, for 10 days or more, provides a significant increase in the moisture biomass content decreasing its energy quality.

The branches had better behaviour during storage, showing more significant improvement of the energy quality of the wood. Fifteen days of storage are sufficient to trunks and branches of trees of the caatinga achieve high energetic quality. The storage of logs and branches of trees of the caatinga can be used as a tool for management of biomass for energy generation, improving energy quality of wood.

\section{ACKNOWLEDGEMENTS}

The company Tractebel Energia SA for the financial support through the project "Analysis of biomass potential use from native forests under sustainable management for power generation" (ANEEL 0403-001/2007), 2006-2007; the company JB Carbon S.A for access to Chapada Gurguéia Farm.

\section{REFERENCES}

ASSOCIAÇÃO BRASILEIRA DE NORMAS TÉCNICAS (ABNT). NBR 13999: papel, cartão, pastas celulósicas e madeira - Determinação do resíduo (cinza) após a incineração a $525^{\circ} \mathrm{C}$. Rio de Janeiro, 2003a. 4 p.
ASSOCIAÇÃO BRASILEIRA DE NORMAS TÉCNICAS (ABNT). NBR 14929: madeira - Determinação do teor de umidade de cavacos - Método por secagem em estufa. Rio de Janeiro, 2003b. 3p.

BRAND, M.A. Energia de biomassa florestal. Rio de Janeiro: Interciência, 2010. 114p.

BRAND, M.A. et al. Potencialidade de uso de biomassa de florestas nativas sob manejo sustentável para a geração de energia. In: CITENEL - CONGRESSO DE INOVAÇ̃̃O TECNOLÓGICA EM ENERGIA ELÉTRICA, 5., 2009, Belém, Pa. Anais... Belém: CITENEL, 2009. p.29.

BRAND, M.A. et al. Influence of storage time on the quality of biomass for energy production in humid subtropical regions. Cerne, v.16, n.4, p.531-537, 2010. Available from: <http://www. scielo.br/pdf/cerne/v16n4/a12v16n4.pdf >. Accessed: Jun. 02, 2013. doi: 10.1590/S0104-77602010000400012.

BRAND, M.A. et al. Storage as a tool to improve wood fuel quality. Biomass and Bioenergy, v.35, p.2581-2588, 2011. Available from: <http://ac.els-cdn.com/S0961953411000808/1s2.0-S0961953411000808-main.pdf? tid=286e48da-e231-11e58ea7-00000aab0f01\&acdnat $=1457113826 \_831 \mathrm{e} 2 \mathrm{e} 6 \mathrm{ba3} 1 \mathrm{~b} 19 \mathrm{c}$ aecdd7fa9e0aabf0b>. Accessed: May 05, 2013. doi: 10.1016/j. biombioe.2011.02.005.

BRASIL. Lei $\mathbf{n}^{\mathbf{0}} \mathbf{1 1 . 2 8 4}$, de 2 de março de 2006. Dispõe sobre a gestão de florestas publicas para a produção sustentável. Available from: <http://www4.planalto.gov.br/legislacao/legislacao-1/leisordinarias/legislacao-1/leis-ordinarias/2006\#content>. Accessed: May 17, 2012.

DEUTSCHES INSTITUT FÜR NORMUNG e. V. DIN 51900: determining the gross calorific value of solid and liquid fuels using the bomb calorimeter, and calculation of net calorific value. Berlim, 2000. 7 p.

FRANCELINO, M.R. et al. Contribuição da caatinga na sustentabilidade de projetos de assentamentos no sertão NorteRio-Grandense. Árvore, v.27, n.1, p.79-86, 2003. Available from: <http://www.scielo.br/pdf/\%0D/rarv/v27n1/15925.pdf>. Accessed: Apr. 10, 2013.

FUNDAČ̃̃ INSTITUTO BRASILEIRO DE GEOGRAFIA E ESTATÍSTICA (IBGE). Manual técnico de vegetação brasileira. Rio de Janeiro, 1992. $271 \mathrm{p}$.

LEAL, I.R. et al. Mudando o curso da conservação da biodiversidade na Caatinga do Nordeste do Brasil. Megadiversidade, v.1, n.1, p.139-141, 2005. Available from: $<$ https://www.researchgate.net/profile/Jose_Maria_Da_Silva2/ publication/260591794 Mudando o curso da Conservao da_biodiversidade_na_Caatinga_do_Nordeste_do_Brasil/ links/0f317531a2c85155fa000000.pdf $>$. Accessed: May 20, 2013.

PAREYN, F.G.C. Os recursos florestais nativos e a sua gestão no estado de Pernambuco - o papel do manejo florestal sustentável. In: GARIGLIO, M.A. et al. (Org.). Uso sustentável e conservação dos recursos florestais da caatinga. Brasília: Serviço Florestal Brasileiro, 2010. p.99-112.

PAUPITZ, J. Elementos da estrutura fundiária e uso da terra no semi-árido brasileiro. In: GARIGLIO, M.A. et al. (Org.). Uso 
sustentável e conservação dos recursos florestais da caatinga. Brasilia: Serviço Florestal Brasileiro, 2010. p.49-62.

PAUPITZ, J. Considerações sobre a extensão florestal: perspectivas e objetivos. Natal: Projeto PNUD/FAO/BRA/87/007, 1989. 8p. (Circular Tecnica, 02).

RAMOS, M.A. et al. Use and knowledge of fuelwood in an area of Caatinga vegetation in NE Brazil. Biomass and bioenergy, v.32, p.510-517, 2008. Available from: <http:/www.sciencedirect. com/science/article/pii/S0961953407002164>. Accessed: Apr. 15, 2013. doi: 10.1016 / j.biombioe.2007.11.015.

SAMPAIO, E.V. de S.B. Caracterização do bioma caatinga características e potencialidades. In: GARIGLIO, M.A. et al. (Org.). Uso sustentável e conservação dos recursos florestais da caatinga. Brasília: Serviço Florestal Brasileiro, 2010. p.29-42.

SANTOS, J.P. et al. Richness and distribution of useful woody plants in the semi-arid region of northeastern Brazil. Journal of Arid Environments, v.72, p.652-663, 2008. Available from: <http://
www.sciencedirect.com/science/article/pii/S0140196307002248>. Accessed: abr. 15, 2013. doi: 10.1016/j.jaridenv.2007.08.004.

SCHACHT, W.H. et al. Response of caatinga vegetation to decreasing levels of canopy cover. Pesquisa Agropecuária Brasileira, v.24, n.11, p.1421-1426, 1989. Available from: <http://www.cnpf.embrapa. br/publica/pfb-revista-antiga/edicoes.htm>. Accessed: Apr. 15, 2013.

SILVA, C.J. da et al. Contribuição de folhas na formação da serrapilheira e no retorno de nutrientes em floresta de transição no norte de Mato Grosso. Acta Amazônica, v.39, n.3, p.591-600, 2009.

SILVA, G.C.; SAMPAIO, E. V. S. B. Biomassas de partes aéreas em plantas da caatinga. Árvore, v.32, n.3, p.567-575, 2008. Available from: <http://www.scielo.br/pdf/rarv/v32n3/a17v32n3>. Accessed: May 20, 2013.

TONIOLO, E.R. et al. Plano de manejo florestal integrado sustentável - Projeto energia verde. Piauí: Redenção do Gurguéia, 2005. 66p. (Relatório técnico). 